\title{
Two new endosymbiotic species of Haplosyllis (Polychaeta: Syllidae) from the Indian Ocean and Red Sea, with new data on $H$. djiboutiensis from the Persian Gulf
}

\author{
P. LATTIG $^{1,2^{*}} \&$ D. MARTIN ${ }^{2}$ \\ 1 Departamento de Biología (Zoología), Laboratorio de Biología Marina e invertebrados, Facultad de Ciencias, \\ Universidad Autónoma de Madrid, calle Darwin 2, 28049 Canto Blanco, Madrid, Spain. e-mail: \\ plattig@gmail.com \\ 2 Centre d'Estudis Avançats de Blanes (CEAB-CSIC), Carrer d'accés a la Cala Sant Francesc 14, 17300 Blanes \\ (Girona), Catalunya, Spain.e-mail:dani@ceab.csic.es \\ * Correspondence author.
}

\begin{abstract}
Previous knowledge on Haplosyllis species from the northern-most regions of the Indian Ocean (including the Red Sea) is confusing, with $H$. djiboutiensis as the only species originally described in the area. This species was later synonymised with $H$. spongicola, which in turn was widely reported all along the region. Among these reports, two referred to populations associated to the sponges Theonella swinhoei Gray, 1868 and Liosina paradoxa Thielle, 1899, from the Red Sea and the Indian Ocean, which proved to have marked enough morphological differences, not only to be distinguished from each other, but also from $H$. spongicola and $H$. djiboutiensis. Accordingly, these specimens are herein illustrated, compared and described as new species. Haplosyllis eldagainoae sp. nov. is distinguished by a broad aciculae, short and curved chaetal mid-joining point and last article of dorsal cirri very long. Haplosyllis giuseppemagninoi $\mathrm{sp}$. nov ressembles $H$. djiboutiensis in chaetal shape and body size (small), but may be differentiated by its broad aciculae and the presence of single chaetae on mid-body parapodia. Finally, the description of $H$. djiboutiensis is complemented with new data on its intra-specific chaetal variability, reproduction and ecology, and the Persian Gulf specimens are compared with those from nearby areas.
\end{abstract}

Keywords

Haplosyllis, sponge endosymbionts, Indian Ocean, Red Sea, New species

Running title

Sponge endosymbiotic Haplosyllis from Indian Ocean 


\section{Introduction}

The northernmost Indian Ocean (i.e. Red Sea, Gulf of Aden, Arabian Sea, Gulf of Oman and Persian Gulf) is regarded as a hot spot of biodiversity, encompassing a large number of endemic species, especially in the Red Sea (Wehe \& Fiege 2002). In the Persian Gulf, most of the cumacean species found in the Iranian coasts were new (Corbera et al. 2005), and the study of the reports of two originally considered cosmopolitan polychaete species belonging to Spiochaetopterus and Owenia revealed to be new species (Bhaud et al. 2003; Martin et al. 2006).

The previous knowledge on Haplosyllis from the region was confusing. H. djiboutiensis Gravier, 1900, the only species originally described for the area, was widely reported all along the region (Amoureux 1983; Amoureux et al. 1978, 1980; Ben-Eliahu 1972, 1977; Ben-Eliahu \& Safriel 1982; Fauvel 1919, 1927, 1933a, b, 1951, 1955; Hartman 1974; Hartmann-Schröder 1960; Kiseleva 1971; Mohammad 1971, 1976, 1980; Monro 1937, 1939). Later, the species was considered as synonymy of the Type species, H. spongicola (Grube, 1855), during decades (Fauvel 1927; Licher 1999; Wehe \& Fiege 2002) and, more recently, it has been confirmed again as valid (Lattig \& Martin 2009).

In the southernmost region, H. trifalcata (Day, 1960) was the single well-defined species, but was scarcely reported, while most reports of the genus refer again to $H$. spongicola (Day 1934; 1960; 1974; Hartmann-Schröder 1960; Kohn \& Lloyd 1973; Magnino \& Gaino 1998; Magnino et al. 1999). Nevertheless, Magnino \& Gaino (1998), and Magnino et al. (1999) already discussed about the morphological differences between the postulated populations of " $H$. spongicola" associated to two different host sponges, Theonella swinhoei Gray, 1868 and Liosina paradoxa Thielle, 1899, from Red Sea and East Africa (Tanzania). According to the current knowledge, these differences were marked enough to differentiate each one from the other, from the Type species, and from all currently known species of the genus (Lattig et al. 2007; Lattig \& Martin 2009; Lattig et al. 2010)

In this paper, these two endobiotic species are formally described, illustrated and compared. In addition, the description of $H$. djiboutiensis is complemented with new data from material collected in the Persian Gulf, which allowed us to describe the intra-specific chaetal variability, as well as to provide new information on its reproduction and ecology, and to compare the Persian Gulf specimens with those from nearby areas.

\section{Material and Methods}

Detailed descriptions of the collection methods for the host sponges and the endosymbiotic syllids are included in Magnino \& Gaino (1998) and Magnino et al. (1999). The specimens from Qatar and Abu Dhabi were collected during routine monitoring surveys carried out by the French company CREOCEAN within the frame of baseline studies for the French company TOTAL. In Qatar, the host sponge was collected on coarse sand bottoms with the help of a van Veen grab $\left(0.1 \mathrm{~m}^{2}\right.$ in surface) after filtering on a mesh of $1 \mathrm{~mm}$ pore size. The retained material was first fixed with a $10 \%$ formalin sea water solution buffered with Borax, stained with Rose Bengal and then preserved in $70 \%$ ethanol until studied. In Abu Dhabi, the samples were obtained from the underwater supports of oil platforms by scrapping 20x20 cm squares and then processed as those from Qatar.

Observations of the Haplosyllis specimens were made using an Olympus SZ30 stereomicroscope and an Olympus CH30 high power microscope. Drawings were made using a camera lucida. Scanning electron microscope (SEM) images were taken at the "Servei de Microscopia Electrònica" of the "Institut de Ciències del Mar" of Barcelona (ICM, CSIC). All specimens were prepared using standard SEM procedures (Martin et al. 2003). 
Specimen's length is indicated as small to mid-sized $(<5-10 \mathrm{~mm}$ long), or large $(>10$ mm long). The terms used for chaetal characters are found in Martin et al. (2003) and Lattig \& Martin (2009). The chaetal characters herein used to describe and compare chaetae are: length of Main Fang (LMF) similar in length or longer than Chaetal Width (SW). Upper Side (US) of Main Fang (MF) with or without denticles. Mid-Joining Point (MJP) between teeth and MF are described as curved (usually short), or straight (perpendicular to MF, being short or long). Proximal and distal apical teeth all equal in size, distal thin and shorter, or proximal smaller. The Type specimens are deposited in the collections of the "Museo Nacional de Ciencias Naturales" (MNCN) of Madrid, Spain. The holotype of H. djiboutiensis were loaned by the "Muséum national d'Histoire naturelle" (MNHN) of Paris, France.

\section{Taxonomic account}

Family Syllidae Grube, 1850

Subfamily Syllinae Grube, 1850

Genus Haplosyllis Langerhans, 1879

Haplosyllis Langerhans, 1879: 527

Trypanosyllis (Trypanoseta) Imajima \& Hartman, 1964: 129.

Geminosyllis Imajima, 1966: 233.—Kudenov \& Harris, 1995: 71, fig. 1.26.—Lattig et al. 2007:

561-562.

\section{Haplosyllis djiboutiensis Gravier, 1900}

(Figs. 1A-H; 2A-B)

Syllis (Haplosyllis) djiboutiensis Gravier, 1900: 147-149, pl. 9, fig. 3.

Haplosyllis djiboutiensis. —Lattig \& Martin, 2009: 18, fig. 12.

Haplosyllis spongicola.-Imajima, 1966: 220-221, tex-fig. a-h._-Lee \& Rho, 1994: 132-134, fig. 1, a-f.

\section{Examined material}

PERSIAN GULF. Qatar. Inside a pink sponge buried in coarse sand, $31.5 \mathrm{~m}$ deep, $51^{\circ} 45.42^{\prime} \mathrm{E}$, $25^{\circ} 16.08^{\prime} \mathrm{N}$ : 33 specimens MNCN 16.01/13174, coll. E. Dutrieux, March 2005. Abu Dhabi. Inside host sponges from the submerged pillars of an oil platform at $\mathrm{Abu} \mathrm{Al}$ Bukhoosh oil field, 25 to $28 \mathrm{~m}$ deep, $53^{\circ} 8.81^{\prime} \mathrm{E}, 25^{\circ} 29.76^{\prime} \mathrm{N}$ : 230 specimens MNCN 16.01/13175; 42 specimens MNCN 16.01/13176; 51 specimens MNCN 16.01/13177; 6 specimens MNCN 16.01/13178; 154 specimens MNCN 16.01/13179. 105 specimens MNCN 16.01/13180; coll. E. Dutrieux, October 2003.

RED SEA, Djubal ("Gubal", Saudi Arabia), type MNHN 48.

\section{Diagnosis}

Body robust, small to mid-sized (Fig. 1A-B); pharynx extending 4-6 segments. Anterior chaetae with short MF and denticles on US (Fig. 1C); mid-body parapodia with 2-3 chaetae of two different sizes (Fig. 1D); smallest chaeta with short proximal tooth (Fig. 1F), largest chaeta with MJP long and straight and apical teeth equal in size (Fig. 1E). 1-2 posterior aciculae. 


\section{Remarks}

The syntype of $H$. djiboutiensis was a poorly preserved specimen, flat (likely as a result of a long time permanence in a microscopic slide), slender, with the proventricle occupying four segments. The re-description of the Type specimen helped to distinguish the species from $H$. spongicola (Lattig \& Martin 2009), but it was not possible to define its morphological variability. The access to the rich Abu Dhabi and Qatar populations allowed us to study this relevant aspect, highly increasing our knowledge on the species. The specimens from Qatar were robust (Fig. 1B), slightly smaller and with a number of dorsal cirri articles similar or slightly lower than the Type specimen. The Abu Dhabi specimens were slender (Fig. 1A), slightly longer and with a wider range in the number of dorsal cirri articles than those of the Type specimen (Table 1). In both cases, the mid-body dorsal cirri alternated in length and never exceeded body width. In addition, both the segments occupied by the proventricle and muscular cell rows were more numerous than in the Type specimen, reaching up to 12 and from 36 to 41, respectively (Table 1). The chaetal shapes followed the same pattern as that of the Type specimen, with short MF on anterior chaeta (Fig. 1C), and mid-body chaetae of two different sizes (Fig. 1D-F). Nevertheless, there were some small variations in MJP, which was shorter in Qatar (Fig. 1D) and longer and more similar to those of the Red Sea type, in Abu Dhabi (Fig. 1E). In addition, the angle between apical teeth in longest chaetae was much wider than the corresponding one in shortest chaetae (Fig. 1E-F).

\section{Reproduction}

Haplosyllis djiboutiensis reproduced by stolons having pairs of black parapodial spots, probably acephalous. One specimen from Abu Dhabi was in reproductive stage, having parapodial spots and swimming capillary chaetae together with 4-5 typical chaetae in the last 12 segments (Fig. 2A-B)

\section{Ecology}

Associated to undetermined sponges both in Qatar and Abu Dhabi, where they reached densities of up to 200 and 900 specimens inside a single, relatively small host individual, respectively. In Qatar, the host sponge inhabited coarse sand bottoms, where it was partly buried with only part of its body protruding out of the sediment surface. In Abu Dhabi, the worms inhabited at least four different host sponge species, which were collected from the submerged pillars of an oil platform.

\section{Distribution}

Red Sea, Persian Gulf, Korea, Southern Japan, Australia (Lattig et al. 2010).

\section{Haplosyllis eldagainoae sp. nov.}

(Figs. 3A-I, 4A-F, 5A-F, 6A-C)

Haplosyllis spongicola: Magnino \& Gaino (1998): fig. 5a-c.-Magnino et al. (1999): fig. 3b-c.

\section{Examined type material}

INDIAN OCEAN. Tanzania: HOLOTYPE MNCN 16.01/13169 and 19 PARATYPES MNCN 16.01/13170: in a small reef bank (Mwamba Kuni) off Bagamoyo (Zanzibar Channel), 6²2' 40" S, 38 58' 40" E, inside the sponge Theonella swinhoei, 15-20 m deep, coll. G. Magnino and E. Gaino, August 1996. 


\section{Additional examined material}

RED SEA. Egypt: 60 specimens MNCN 16.01/13171, in a fringing reef near Hurghada (Gulf of Suez), $27^{\circ} 35^{\prime} 36.60^{\prime}$ ' N, 33 $33^{\circ}$ ' 3.12" E, inside the sponge Theonella swinhoei, 7 to $22 \mathrm{~m}$, coll. G. Magnino and E. Gaino, Spring, 1996.

\section{Description}

Body translucent, small-sized, 2-4 mm long, about $0.3 \mathrm{~mm}$ wide excluding parapodia, for 16-30 chaetigers (Fig. 4A). Dark green in vivo, pale yellow when preserved; with small dorsal granules, more evident on posterior segments and parapodial lobes (Fig. 3A, B). Prostomium subpentagonal, wider than longer, two pairs of small red eyes in trapezoidal arrangement. Nuchal organs between prostomium and peristomium as two ciliated grooves (Fig. 4D). Median antenna inserted on middle of prostomium (8-18 articles); lateral antennae on anterior margin (5-9 articles) (Fig. 4B). Palps long, broadly triangular, fused at their bases, with upper-ventral groups of cilia as sensory organs. Pharynx orange, extending through 3-5 segments, as wide as proventricle, with large anterior tooth, crown of 9-10 soft papillae and inner ring of cilia (Fig. 4C); papillae with cilia similar to those on palps. Proventricle dark-brown, cylindrical, extending through 3-5 segments, with 25-26 muscular cell-rows (Fig. 3A). Peristomium well defined, shorter than subsequent segments. Dorsal tentacular cirri longer (7-16 articles) than ventral ones; anterior dorsal cirri slender, similar to tentacular cirri, with last article long, triangular (Figs. 3A; $5 \mathrm{~A})$. First dorsal cirri longer than remaining ones (5-16 articles), second and third short (1-2, 14 articles, respectively); fourth long (2-7 articles), fifth short (1-2 articles), sixth longer (2-5 articles) (Figs 3A; 4B). Subsequent cirri short, with 1-3 articles, last article longer (Fig. 5B). Ventral cirri digitiform, not longer than parapodial lobes, gradually shortening to posterior end (Fig. 3 C, D). Chaetae all bidentate, 2-3 per parapodium, broad, all similar in shape, with LMF similar to SW; MJP very short, curved; denticles on US of MF absent or very short; apical teeth equal in length, long, well separated by wide angle (Figs 3F,G, I; 4E; 5E). One acicula per each parapodium, broader than chaetae, with curved upwards-directed tip (Figs 3E, H; 5D, F) sometimes protruding out of parapodia (Fig. 4F). Pygidium with two short anal cirri (1-2 articles) (Fig. 5C).

\section{Remarks}

Haplosyllis eldagainoae sp. nov. was first reported as H. spongicola (Magnino \& Gaino 1998; Magnino et al. 1999) but is easily distinguishable from all previously known species of the genus by its broad aciculae, short and curved MJP and, specially, by the last article of dorsal cirri, which is very long. H. eldagainoae sp. nov. more closely resembles $H$. basticola in body size (small) and chaetal shape. However, the latter has much shorter dorsal cirri having a short last article (long, triangular in the new species).

\section{Etymology}

The species name "eldagainoae" is dedicated to Elda Gaino, who collected the material and participated in the description of the ecology of the different populations and their relationships with the host sponges.

\section{Reproduction}

Some Red Sea females were in reproductive stage (Fig. 6B-C), with the last 13 segments containing numerous oocytes. Numerous juveniles less than 15 chaetigers long (Fig. 6A) share the canals of the host sponge with the adults. 


\section{Ecology}

The two examined populations of $H$. eldagainoae sp. nov. from Egypt (Red Sea) and Tanzania (Indian Ocean) are strict endosymbionts of the sponge Theonella swinhoei. The worms inhabit the canals of the aquiferous system of the host, both the inhalant and exhalant parts. There is usually one specimen per canal, but occasionally two or three can be found inside the same canal, reaching densities of about 70 specimens per $\mathrm{cm}^{3}$. Living specimens share the dark green colour of the host sponge and seemed to feed on the host, likely supporting a parasitic relationship (Magnino \& Gaino 1998; Magnino et al. 1999), however, the host sponge supports the presence of the worm population. Recently, a mutualistic character has been postulated for similar relationships between syllids and sponges, with the worms being able to defence the host from external predators (Martin et al. 2009), and so this could be the right situation in this case too.

\section{Distribution}

Red Sea (Egypt); Indian Ocean (Tanzania).

\section{Haplosyllis giuseppemagninoi sp. nov.}

(Figs 7A-I; 8A-I; 9A-C)

Haplosyllis spongicola: Magnino \& Gaino, 1998: fig. 5, d-f.

\section{Examined material}

Indian Ocean, Tanzania (near Bagamoyo). HOLOTYPE MNCN 16.01/13172, and 230 PARATYPES (plus 2 for SEM) 16.01/13173: in a wide reef inlet with abundant mangroves, inside the sponge Liosina paradoxa, from 7-22 m deep, coll G. Magnino and E. Gaino, August 1996.

\section{Description}

Body robust, small to medium-sized, $2-5 \mathrm{~mm}$ long, $0.3-0.5 \mathrm{~mm}$ wide excluding parapodia, for 28-40 segments (22-23 on juveniles) (Fig. 8A). White pale to orange in vivo, pale yellow when preserved. Scarce round, small, dorsal granules on posterior segments, almost absent from midbody and anterior segments. Prostomium subpentagonal, wider than long, with two pairs of small red eyes in trapezoidal arrangement. Nuchal organs between prostomium and peristomium as two ciliated grooves. Median antenna inserted on middle of prostomium (14-23 articles); lateral antennae on anterior margin (7-12 articles). Palps long, broadly triangular, fused at their bases; sensory organs of palps not seen. Pharynx orange, extending through $2-4$ segments, as wide as proventricle, with large anterior tooth, an inner ring of cilia and crown of 10 soft papillae (Fig. 8B) with sensory organs as tufts of cilia on ventral side. Proventricle dark-brown, cylindrical, extending through 3-7 segments, with 25-28 muscular cell-rows (Fig. 7A). Peristomium well defined, shorter than subsequent segments. Dorsal tentacular cirri longer (9-19 articles) than ventral ones. Anterior dorsal cirri similar to antennae and tentacular cirri. First dorsal cirri longer than remaining ones (10-21 articles), second and third short (3-9, 3-11 articles, respectively); fourth slightly longer (4-14 articles), fifth short (2-6 articles), sixth longer (2-10 articles) (Fig. 8C). Subsequent cirri short, with 1-8 articles (Fig. 8E). Cirri from posterior segments very short, smooth or with 2-3 articles (Figs 7B; 8D). Ventral cirri digitiform, not longer than parapodial lobes, gradually shorter to posterior end (Fig. 7C-D). Chaetae all bidentate, two on anterior parapodia (Fig. 8F); one at mid-body segments (Figs 7E; 8G-H; 9A), 2-4 on posterior parapodia 
(Figs 7G-H; 8I); LMF similar to SW; MJP straight, relatively long on anterior and posterior chaetae, vs. short, curved at mid-body; denticles on US of MF absent or very short; apical teeth equal in length, long, separated by wide angle. Two aciculae in anterior parapodia (one straight, other with slightly curved tip); from proventricle region to posterior end one acicula per parapodium, broad, with curved upwards-directed tips (Fig. 7F, I) sometimes protruding out of parapodia (Fig. 9B-C). Pygidium with two short anal cirri (3-10 articles) (Fig. 7B).

\section{Remarks}

Haplosyllis giuseppemagninoi sp. nov. was first reported as H. spongicola (Magnino \& Gaino 1998). However, it is easily distinguishable from the Type species of the genus by its broad acicula and the presence of a single chaeta (occasionally two) on middle parapodia. The new species more closely resembles $H$. djiboutiensis in chaetal shape and body size (small). However, the latter has two chaetae on each mid-body and posterior parapodia, which are different in shape and size, one with MJP straight and long (Fig. 1E), and a smaller one with short MJP and apical teeth separated by wide angle (Fig. 1F). The new species has only one chaeta per parapodia with short MJP, or rarely two chaetae but similar in shape and size (Fig. 7G-I). In addition, the midbody cirri in $H$. djiboutiensis are clearly articulated instead of short, sometimes smooth in $H$. giuseppemagninoi sp. nov.

Haplosyllis giuseppemagninoi sp. nov. may be easily distinguished from $H$. eldagainoae sp. nov. in life habits (i.e. being strict endosymbionts of L. paradoxa and T. swinhoei, respectively), as well as in chaetal and cirri shape, particularly due to the short MJP and the long and triangular upper article of all cirri of $H$. eldagainoae sp. nov.

\section{Etymology}

The species name "giuseppemagninoi" is dedicated to Giuseppe Magnino, who collected the material and participated in the description of the ecology of the different populations and their relationships with the host sponges. He also kindly loaned us both the Haplosyllis and the host sponges.

\section{Reproduction}

Not seen.

\section{Ecology}

Haplosyllis giuseppemagninoi sp. nov. is a strict symbiont of Liosina paradoxa, inhabiting a small reef bank of the Zanzibar Channel (Indian Ocean), at 7-22 m deep. The worms inhabit both the inhalant and exhalant canals of the aquiferous system of the host sponge, usually one specimen per canal, but occasionally two or three were in the same canal. The colour of both worms body and gut contents mimics that of the host sponge, likely supporting a parasitic relationship (Magnino \& Gaino 1998), but see discussion above on the ecology of $H$. eldagainoae sp. nov.

\section{Distribution}

Indian Ocean, Tanzania.

\section{Acknowledgements}

We are grateful to G. Magnino for kindly loaning us the endosymbiotic Haplosyllis populations associated to Theonella swinhoei and Lyosina paradoxa. The SEM images were made with the 
help of Jose Manuel Fortuño from the SEM Service of the ICM-CSIC. First author would like to thank to CEAB-CSIC for the laboratory facilities and financial support. The study was partly financed by the agreement between the CEAB-CSIC and CRÉOCÉAN (France) and was partly sponsored by TOTAL (France). The paper is a contribution to the Consolidated Research Group 2009SRG665 of the "Generalitat de Catalunya".

\section{References}

Amoureux L. 1983. Annelides polychetes du golfe d'Aqaba (Mer Rouge) description d'un genere nouveau et de deux especes nouvelles. Bulletin du Museum National d'Histoire Naturelle Paris 3, 723-742.

Amoureux L, Josef G, O'Connor B. 1980. Annélides Polychètes de l'éponge Fasciospongia cavernosa Schmidt. Cahiers de Biologie Marine 21, 387-392.

Amoureux L, Rullier F, Fishelson L. 1978. Systematique et ecologie d'annelides polychetes de la presqu'il du Sinai. Israel Journal of Zoology 27, 57-163.

Ben-Eliahu MN. 1972. Polychaeta errantia from the Suez Canal. Israel Journal of Zoology 21, 189-237.

Ben-Eliahu MN. 1977. Polychaete cryptofauna from rims of similar intertidal vermetid reefs on the Mediterranean coast of Israel and in the Gulf of Elat: Syllinae and Eusyllinae (Polychaete Errantia: Syllidae). Israel Journal of Zoology 26, 1-58.

Ben-Eliahu MN, Safriel UN. 1982. A comparison between species diversities of polychaetes from tropical and temperate structurally similar rocky intertidal habitats. Journal of Biogeography 9, 371390.

Bhaud M, Martin D, Gil J. 2003. Spiochaetopterus creoceanae, a new species of Chaetopteridae (Polychaeta) from the Persian Gulf belonging to the costarum-complex. Scientia Marina 67, 99-105.

Corbera J, Tirado P, Martin D. 2005. Cumaceans (Crustacea: Peracarida) from the Persian Gulf. Zootaxa 1087, 1-31.

Day JH. 1934. On a collection of South African Polychaeta, with a catalogue of the species recorded from South Africa, Angola, Mosambique and Madagascar. Journal of the Linnean Society of London 39, 15-82.

Day JH. 1960. The Polychaete fauna of South Africa. Part 5. Errant species dredged off Cape coasts. Annals of the South African Museum 45, 261-373.

Day JH. 1974. The ecology of Morrumbene estuary, Moçambique. Transactions of the Royal Society of South Africa 41, 43-97.

Fauvel P. 1919. Annélides Polychètes de Madagascar, de Djibouti, et du Golfe Persique. Archives de Zoologie Expérimentale et Générale 58, 315-473.

Fauvel P. 1927. Rapport sur les Annélides Polychètes errantes. Zoological Results of the Cambridge Expedition to the Suez Channel, 1924. Transactions of the Zoological Society of London 22, 411439.

Fauvel P. 1933a. Mission Robert Ph. Dollfus en Egypte. Annélides Polychètes. Mémoires présentes a l'institut d'Egypte et publies sous les auspices de sa Majesté Fouad Ier, Roi d'Egypte, 21, 31-83.

Fauvel P. 1933b. Résumé analytique du mémoire sur les Polychètes. Bull. Inst. Egypte 15, 131-144.

Fauvel P. 1951. Annélides Polychètes du Golfe de Tadjonoa receuillies par M. J.-L. Dantan en 1933, au cours de pêches nocturnes à la lumière (suite). Bulletin du Muséum d'Histoire Naturelle Paris, 23, 381-389.

Fauvel P. 1955. Annélides Polychètes de la Croisière de la Calypso en Mer Rouge en 1952. Resultats Scientifique de les Campagnes de Calypso, 3, 101-120.

Gravier C. 1900. Contribution à l'étude des Annélides Polychètes de la Mer Rouge. Première partie. Nouvelles Archives du Museum d'Histoire Naturelle Paris, 2, 137-282.

Grube A. 1850. Die Familien Anneliden. Archiv. Für Naturg., Berlin, 16, 249-364.

Hartman O. 1974. Polychaetous annelids of the Indian Ocean including an account of species collected by members of the international Indian Ocean expeditions, 1963-'64 and a catalogue and bibliography of the species from India. Journal of the Marine Biological Association of India 16, 191-252.

Hartmann-Schröder G. 1960. Polychaeten aus dem Roten Meer. Kieler Meeresforschungen 16, 69-125.

Imajima M. 1966. The Syllidae (Polychateous Annelids) from Japan (IV) Syllinae (1). Publications of the seto Marine Biological Laboratory XIV, 218-252. 
Imajima M, Hartman O. 1964. The Polychaetous annelids of Japan, Part I. Allan Hancock Foundation Publications, occasional paper 26, 1-452.

Kiseleva MI. 1971. Qualitative composition and quantitative distribution of Polychaeta in the Red Sea. In: Vodyanitzkii, V.A. (Ed.) [Benthos of the Red Sea's shelf]. Naukova Dumka, Kiev, pp. 44-76.

Kohn AJ, Lloyd MC. 1973. Marine polychaete annelids of Easter Island. Internationale Revue der gesammten Hydrobiologie, 58, 691-712.

Kudenov JD, Harris LH. 1995. Family Syllidae Grube, 1850. In: Blake JA, Hilbig B, Scout PH. (Eds.) [Taxonomic atlas of the benthic fauna of the Santa Maria Basin and western Santa Barbara Channel, vol. 5, part 2]. Santa Barbara Museum of Natural History, Santa Barbara, California, pp. 1-99

Langerhans P. 1879. Die Wurmfauna von Madeira. Zeitschrift Für Wissenschaftliche Zoology, 32, 513592.

Lattig P, Martin D. 2009. A taxonomic revision of the genus Haplosyllis Langerhans, 1887 (Polychaeta: Syllidae: Syllinae). Zootaxa 2220, 1-40.

Lattig P, Martin D, San Martín G. 2010. Syllinae (Syllidae: Polychaeta) from Australia. Part 4. The genus Haplosyllis Langerhans, 1879 (Polychaeta: Syllidae: Syllinae) Zootaxa 2552, 1-36.

Lattig P, San Martín G, Martin D. 2007. Taxonomic and morphometric analyses of the Haplosyllis spongicola complex (Polychaeta: Syllidae: Syllinae) from Spanish seas, with re-description of the type species and descriptions of two new species. Scientia Marina 71, 551-570.

Lee JW, Rho BJ. 1994. Systematic Studies on Syllidae (Annelida, Polychaeta) from the South Sea and the East Sea in Korea. The Korean Journal of Systematic Zoology, 10, 131-144.

Licher F. 1999. Revision der Gattung Typosyllis Langerhans, 1879 (Polychaeta: Syllidae). Morphologie, Taxonomie und Phylogenie. Abhandlungen der Senckenbergischen Naturforschenden Gesellschaft $551,1-336$.

Magnino G, Gaino E. 1998. Haplosyllis spongicola (Grübe) (Polychaeta, Syllidae) associated with two species of sponges from east Africa (Tanzania, Indian Ocean). P.S.Z.N. I: Marine Ecology 19, 77-87.

Magnino G, Sarà A, Lancioni T, Gaino E. 1999. Endobionts of the coral reef sponge Theonella swinhoei (Porifera, Demospongiae). Invertebrate Biology 118, 213-220.

Martin D, Aguado MT, Britayev TA. 2009. Review of the symbiotic genus Haplosyllides, with description of a new species. Zoological Science 26, 646-655.

Martin D, Britayev TA, San Martín G, Gil J. 2003. Inter-population variability and character description in the sponge associated Haplosyllis spongicola complex (Polychaeta: Syllidae). Hydrobiologia 496, $145-162$.

Martin D, Koh BS, Bhaud M, Gil J, Dutrieux É. 2006. The genus Owenia (Annelida, Polychaeta) in the Persian Gulf, with description of a new species, Owenia persica. Organisms Diversity and Evolution, 6, 325-326.

Mohammad MBM. 1971. Intertidal polychaetes from Kuwait, Arabian Gulf, with descriptions of three new species. Journal of Zoology163, 285-303.

Mohammad MBM. 1976. Relationships between the biofouling and growth of the pearl oyster Pinctada fucata (Gould) in Kuwait, Arabian Gulf. Hydrobiologia, 51, 129-138.

Mohammad MBM. 1980. Polychaete annelids from Kuwaitian islands, Arabian Gulf, with descriptions of four new species. Zoological Journal of the Linnean Society of London 69, 31-42.

Monro CCA. 1937. The John Murray Expedition 1933-34. Polychaeta. Scientific Reports, Zoology 4, 243-321.

Monro CCA. 1939. Polychaeta of 'Rosaura' Expedition. Novitates Zoologicae 41, 345-354.

Wehe T, Fiege D. 2002. Annotated checklist of the polychaete species of the seas surrounding the Arabian Peninsula: Red Sea, Gulf of Aden, Arabian Sea, Gulf of Oman, Arabian Gulf. Fauna of Arabia 19, 7-238. 
Table 1. Summary of measurements of the most relevant morphological features of Haplosyllis djiboutiensis from Red Sea (type) and Persian Gulf (Qatar and Abu Dhabi). N: number of measured specimens; Max: maximun; Min: minimum; avg: average; SD: standard deviation.

\begin{tabular}{lccccccccccc}
\hline & & \multicolumn{4}{c}{ QATAR } & \multicolumn{6}{c}{ ABU DHABI } \\
\hline & Polytype & $\mathbf{N}$ & Max & Min & Av & SD & N & Max & Min & Av & SD \\
\hline Body lenght (mm) & $\mathbf{8}$ & 10 & 4 & 2 & 3 & 1 & 26 & 9 & 3 & 5 & 2 \\
Body chaetigers & $\mathbf{3 8}$ & 10 & 42 & 21 & 29 & 7 & 32 & 57 & 25 & 40 & 9 \\
Proventricle & & & & & & & & & & & \\
Segments & $\mathbf{4}$ & 10 & 12 & 5 & 8 & 2 & 32 & 8 & 4 & 6 & 1 \\
muscular cell rows & $\mathbf{3 6}$ & 10 & 36 & 27 & 33 & 3 & 32 & 41 & 3,7 & 33 & 6 \\
Antennae articles & & & & & & & & & & & \\
Central antennae & $\mathbf{2 2}$ & 8 & 25 & 10 & 16 & 5 & 14 & 21 & 12 & 17 & 3 \\
Lateral antennae & $\mathbf{1 4}$ & 10 & 18 & 7 & 11 & 3 & 29 & 29 & 8 & 14 & 5 \\
Dorsal C. articles & & & & & & & & & & & \\
DT cirri & $\mathbf{1 3}$ & 10 & 18 & 7 & 13 & 3 & 32 & 40 & 10 & 20 & 7 \\
1 & $\mathbf{2 3}$ & 9 & 25 & 11 & 19 & 5 & 30 & 44 & 10 & 23 & 8 \\
2 & $\mathbf{1 2}$ & 10 & 13 & 2 & 7 & 4 & 30 & 21 & 4 & 11 & 5 \\
3 & $\mathbf{1 5}$ & 10 & 15 & 4 & 8 & 4 & 31 & 30 & 5 & 13 & 5 \\
4 & $\mathbf{1 9}$ & 9 & 16 & 5 & 11 & 4 & 30 & 27 & 8 & 16 & 5 \\
5 & $\mathbf{1 0}$ & 9 & 9 & 2 & 6 & 2 & 31 & 23 & 4 & 9 & 4 \\
6 & $\mathbf{1 5}$ & 9 & 13 & 3 & 9 & 3 & 30 & 24 & 5 & 12 & 5 \\
7 & $\mathbf{8}$ & 9 & 8 & 2 & 5 & 2 & 31 & 14 & 3 & 7 & 3 \\
8 & $\mathbf{1 0}$ & 8 & 8 & 4 & 5 & 1 & 28 & 20 & 4 & 7 & 3 \\
9 & $\mathbf{1 1}$ & 9 & 9 & 2 & 6 & 2 & 29 & 22 & 3 & 10 & 4 \\
10 & $\mathbf{6}$ & 7 & 7 & 2 & 5 & 2 & 30 & 18 & 3 & 7 & 3 \\
Pygidium articles & & 2 & 7 & 6 & 7 & 1 & 14 & 11 & 1 & 5 & 3 \\
\hline
\end{tabular}



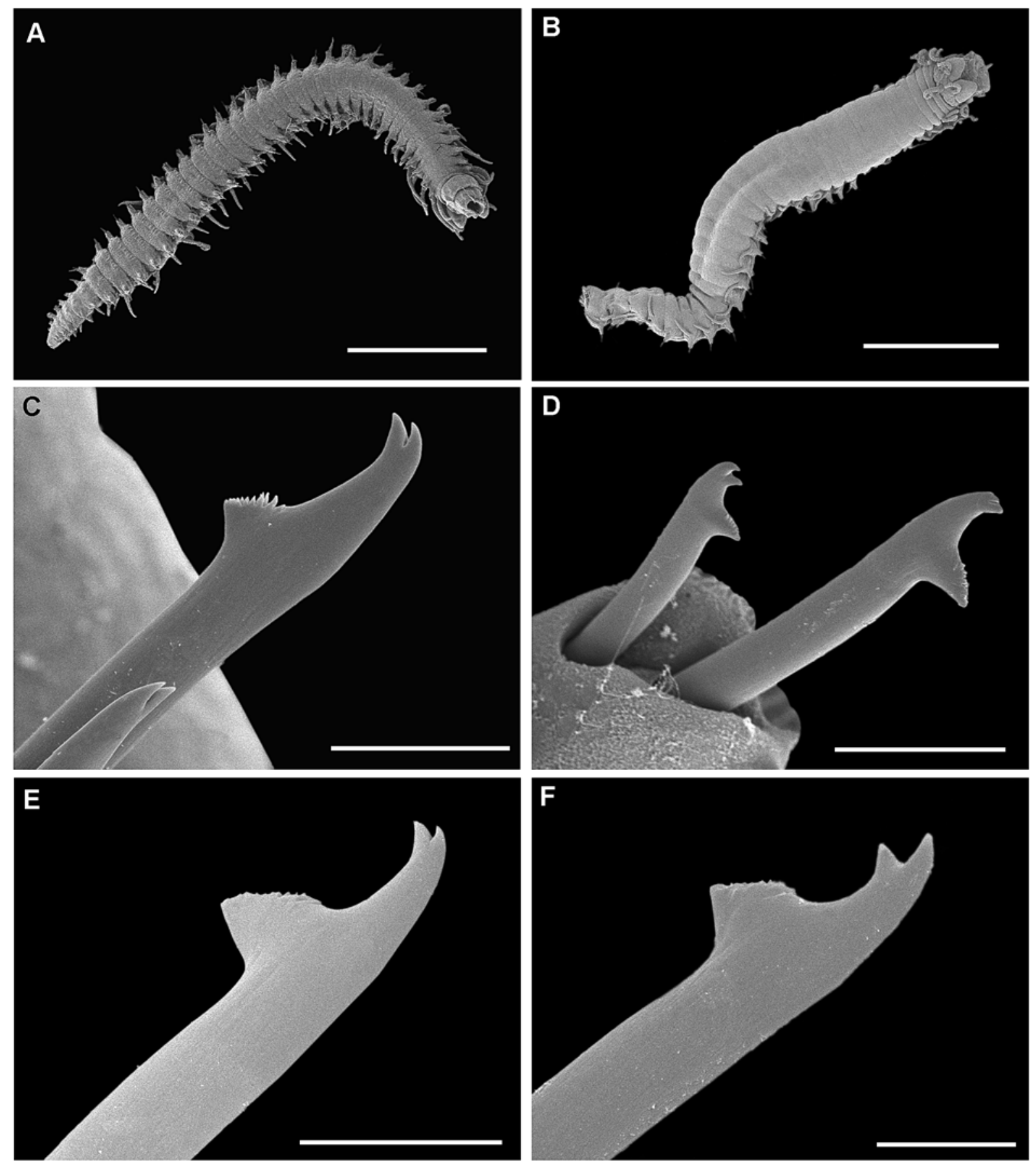

Figure 1. SEM microphotographs of Haplosyllis djiboutiensis from the Persian Gulf. A) Whole body, ventral view, posterior segments regenerating after reproduction. B) Whole body, dorsal view. C) Anterior chaeta. D) Mid-body chaetae. E) Long mid-body chaeta. F) Short mid-body chaeta. Abu Dhabi (MMCN 16.01/13180): A, C-D. Qatar (MNCN 16.01/13174): B, E-F. Scale bars: A-B = 1 mm, C, E = $10 \mu \mathrm{m}, \mathrm{D}=20 \mu \mathrm{m}, \mathrm{F}=5 \mu \mathrm{m}$. 


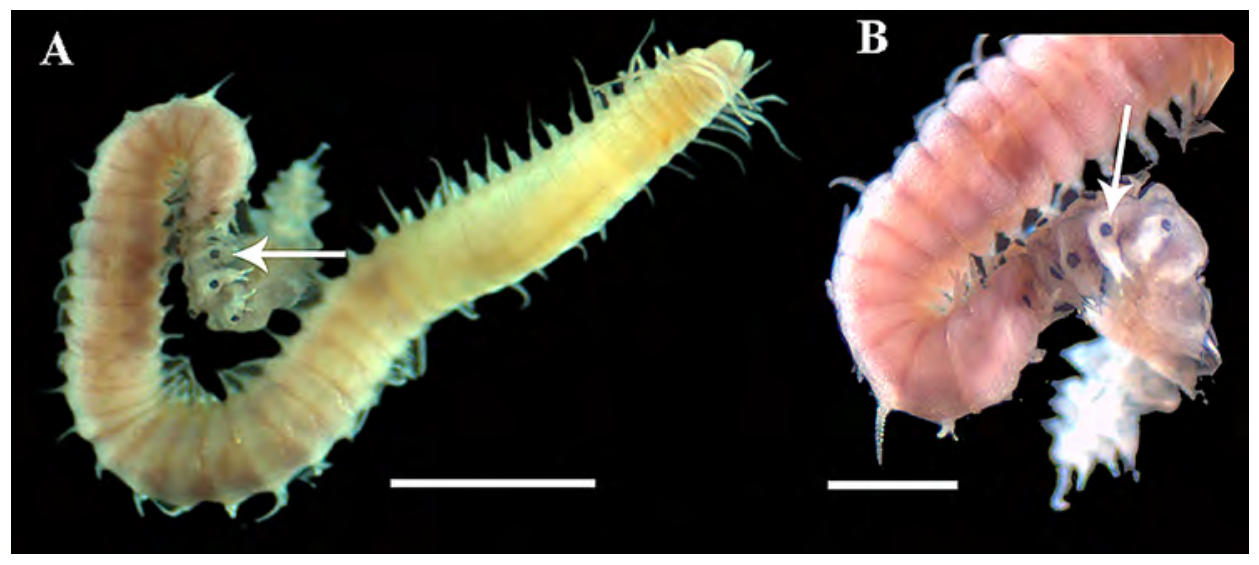

Figure 2. Haplosyllis djiboutiensis. Adult specimen from the Persian Gulf (Abu Dhabi) in reproductive stage. A) Complete specimen, with last 12 segments at beginning of stolonization process. B) Detail of the modified region. Arrows pointing the position of ocular spots. (MMCN 16.01/13180). Scale bars: $\mathrm{A}=$ $1 \mathrm{~mm}, \mathrm{~B}=800 \mu \mathrm{m}$.

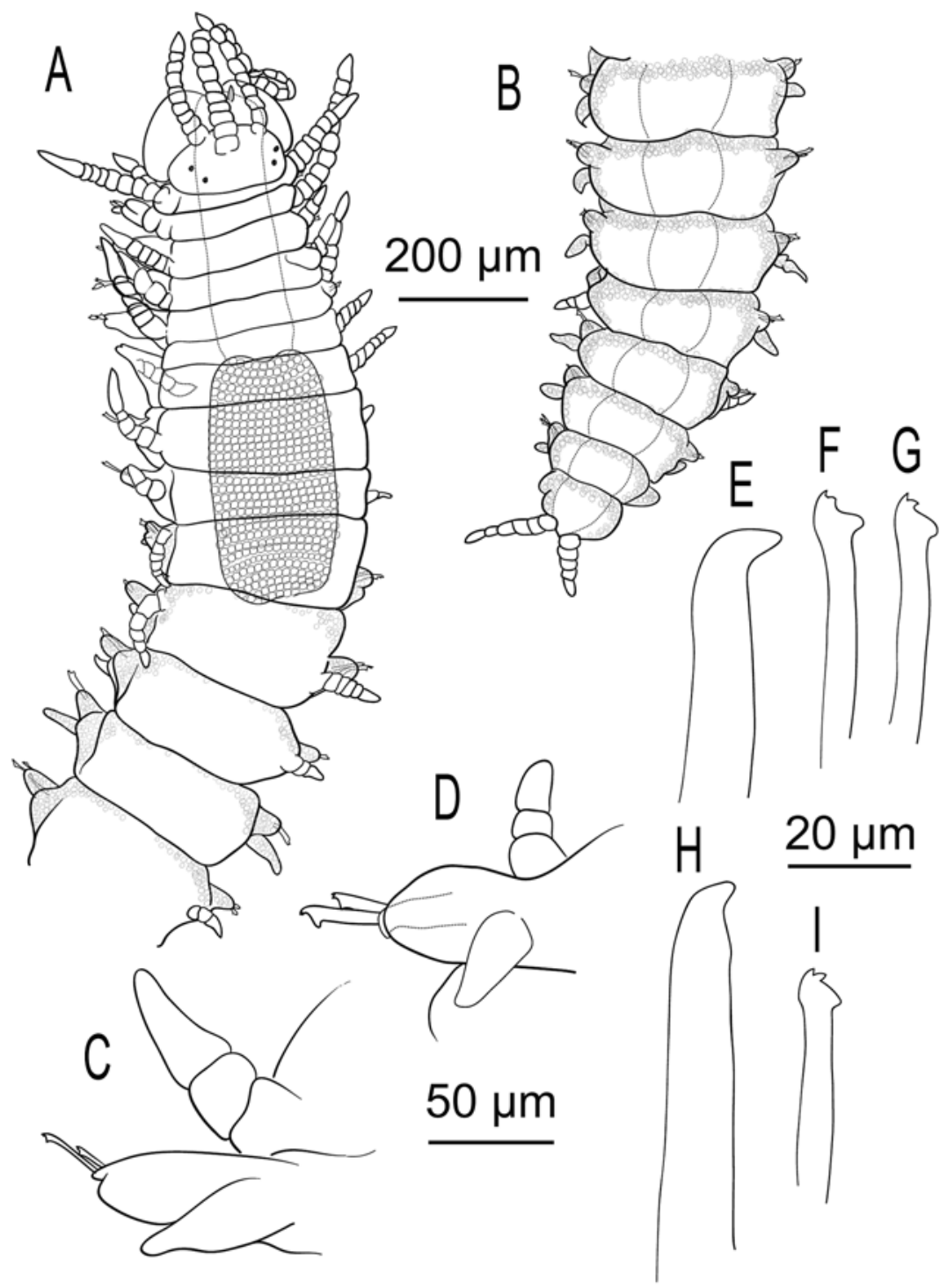

Figure 3. Haplosyllis eldagainoae sp. nov. A) Anterior and mid-body view. B) Posterior region. C) Parapodium from anterior region. D) Parapodium from mid-body. E) Mid-body and posterior acicula. FG) Mid-body and posterior chaetae. H) Posterior aciculae. I) Posterior chaetae. From Tanzania (MNCN 16.01/13170) 

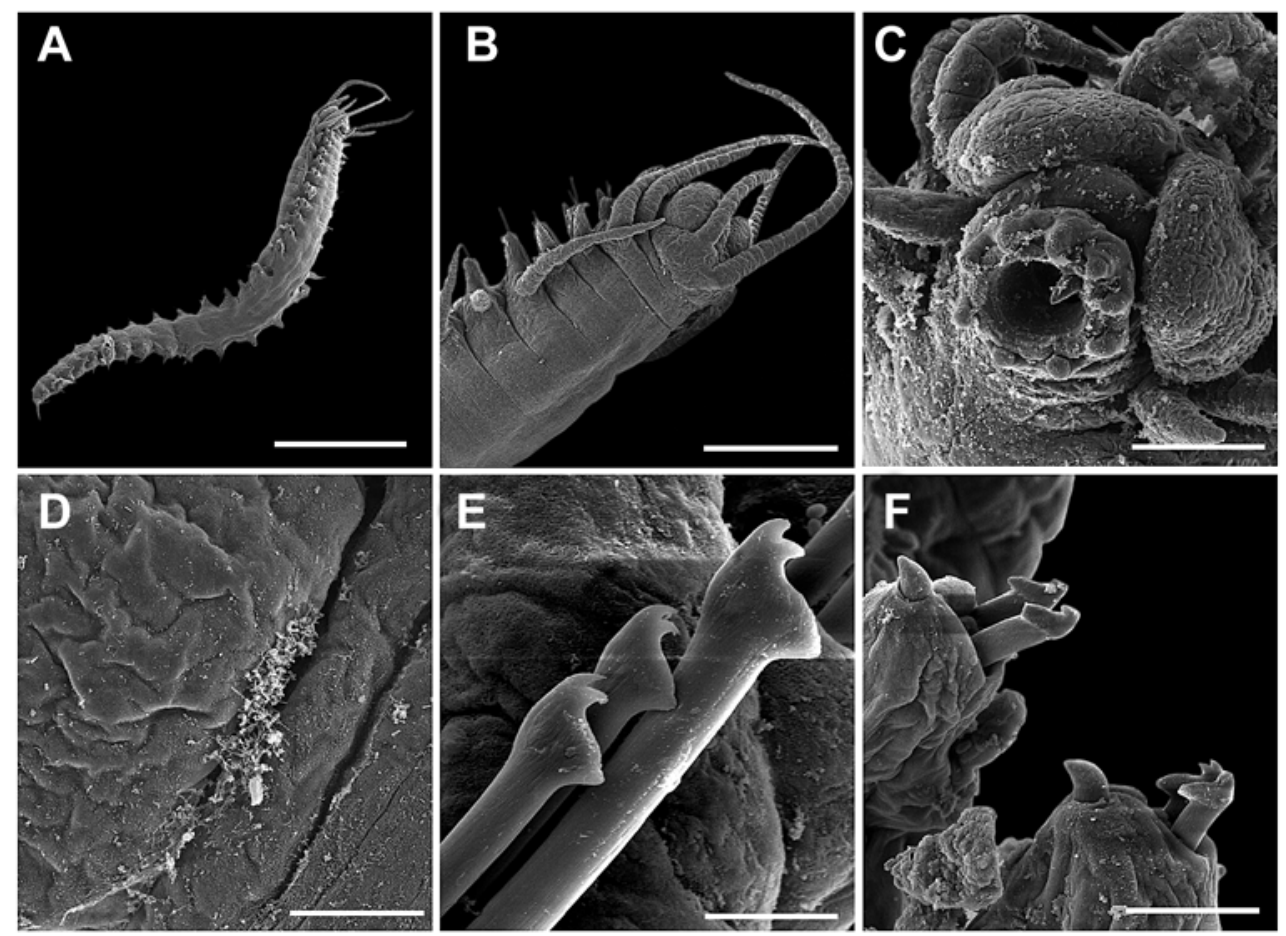

Figure 4. SEM microphotographs of Haplosyllis eldagainoae sp. nov. A) Whole body, ventral view. B) Anterior end, dorsal view. C) Anterior end showing pharynx with soft papillae, ventral view. D) Detail of one side of nuchal organs. E) Anterior chaetae. F) Posterior parapodia, with chaetae and acicula protruding out of parapodium. Paratypes from Tanzania (MNCN 16.01/13170); E-F from Red sea (MNCN 16.01/13171). Scale bars: $\mathrm{A}=750 \mu \mathrm{m}, \mathrm{B}=230 \mu \mathrm{m}, \mathrm{C}=75 \mu \mathrm{m}, \mathrm{D}=27 \mu \mathrm{m}, \mathrm{E}=7.5 \mu \mathrm{m}, \mathrm{F}=23$ um. A-D
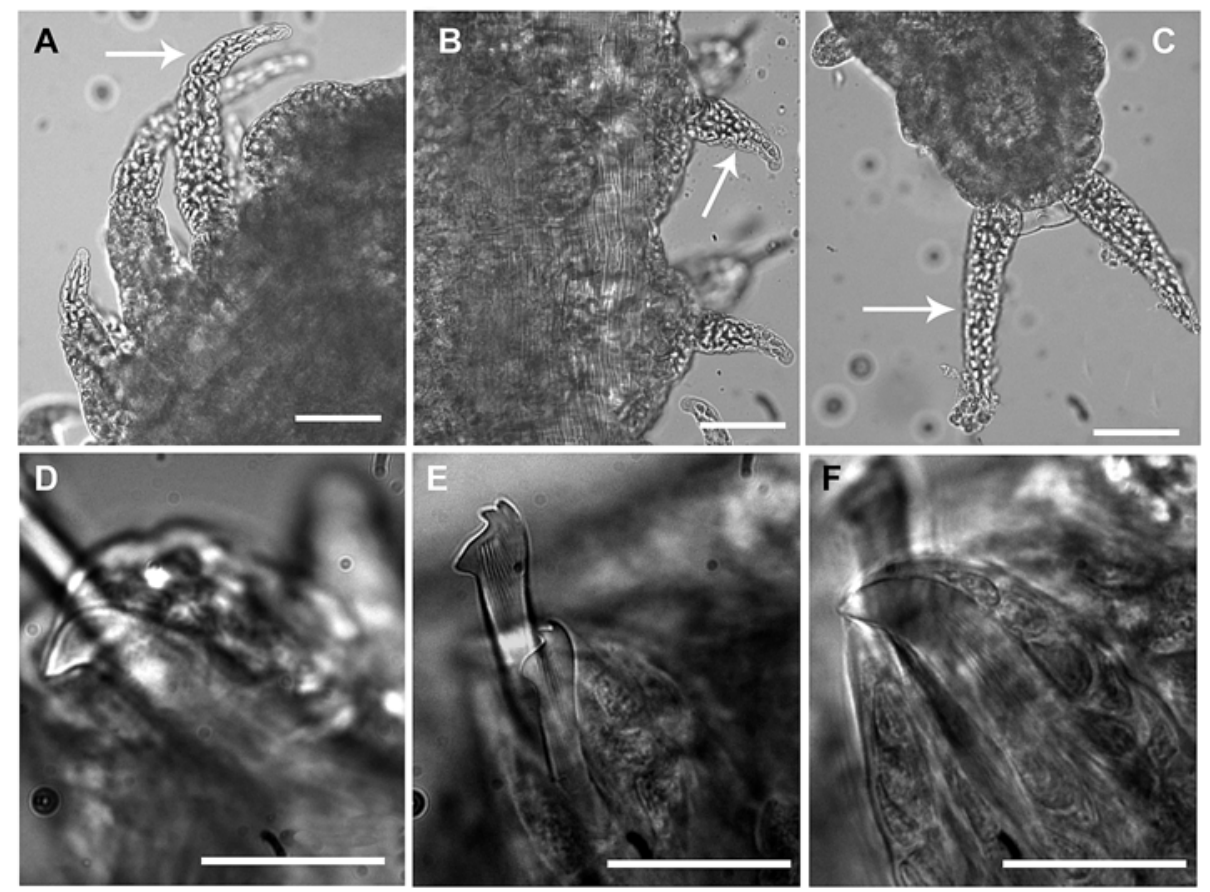

Figure 5. Light microphotographs of Haplosyllis eldagainoae sp. nov. A) Dorsal cirri, anterior end. B) Mid-body dorsal cirri. C) Anal cirri of pigidium. D) Acicula, mid-body. E) Chaetae, mid-body. F) Posterior acicula. Arrows of A and B pointing upper article of cirri, of C pointing long article. Scale bars: $\mathrm{A}-\mathrm{C}=50 \mu \mathrm{m}, \mathrm{D}-\mathrm{F}=20 \mu \mathrm{m}$. From Red Sea (MNCN 16.01/13171) 

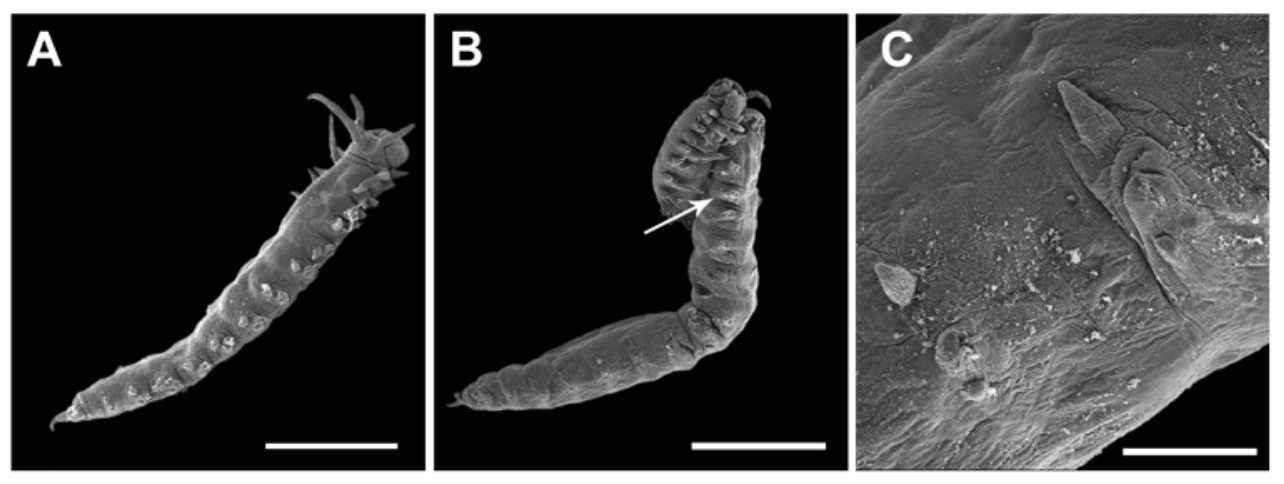

Figure 6. Haplosyllis eldagainoae sp. nov. SEM microphotographs. A) Juvenile. B) Adult in reproductive stage, with last segments developing a stolon. C) Detail of parapodium of a reproductive segment. Scale bars: $\mathrm{A}=0.38 \mu \mathrm{m}, \mathrm{B}=0.60 \mu \mathrm{m}, \mathrm{C}=0.86 \mu \mathrm{m}$.

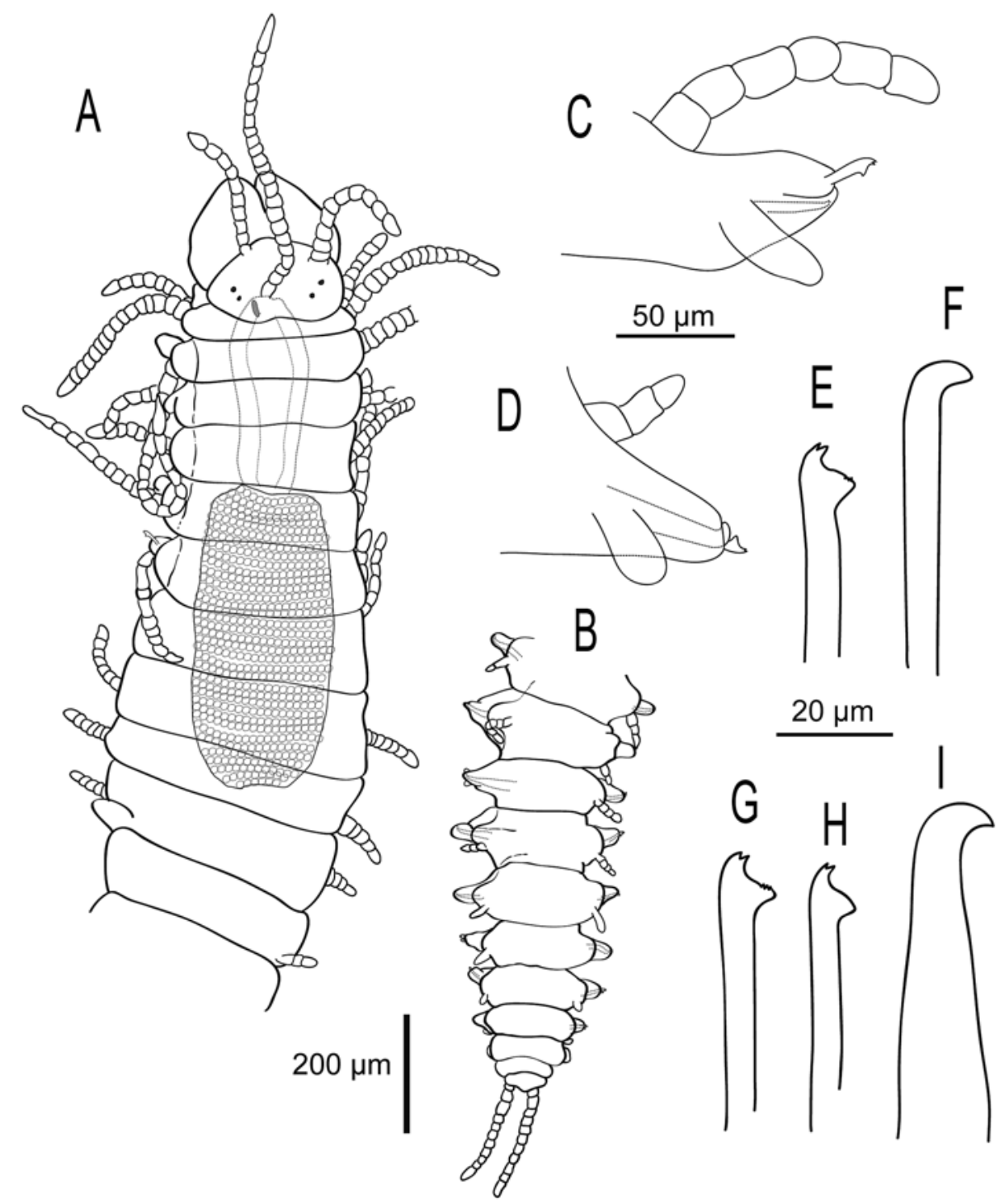

Figure 7. Haplosyllis giuseppemagninoi sp. nov. A) Anterior and mid-body view. B) Posterior region. C) Parapodium, anterior body. D) Parapodium, posterior body-end. E) Chaetae, mid-body. F) Aciculae, midbody. G) Large posterior chaeta. H) Small posterior chaeta. I) Posterior acicula. Paratype (MNCN $16.01 / 13173)$. 

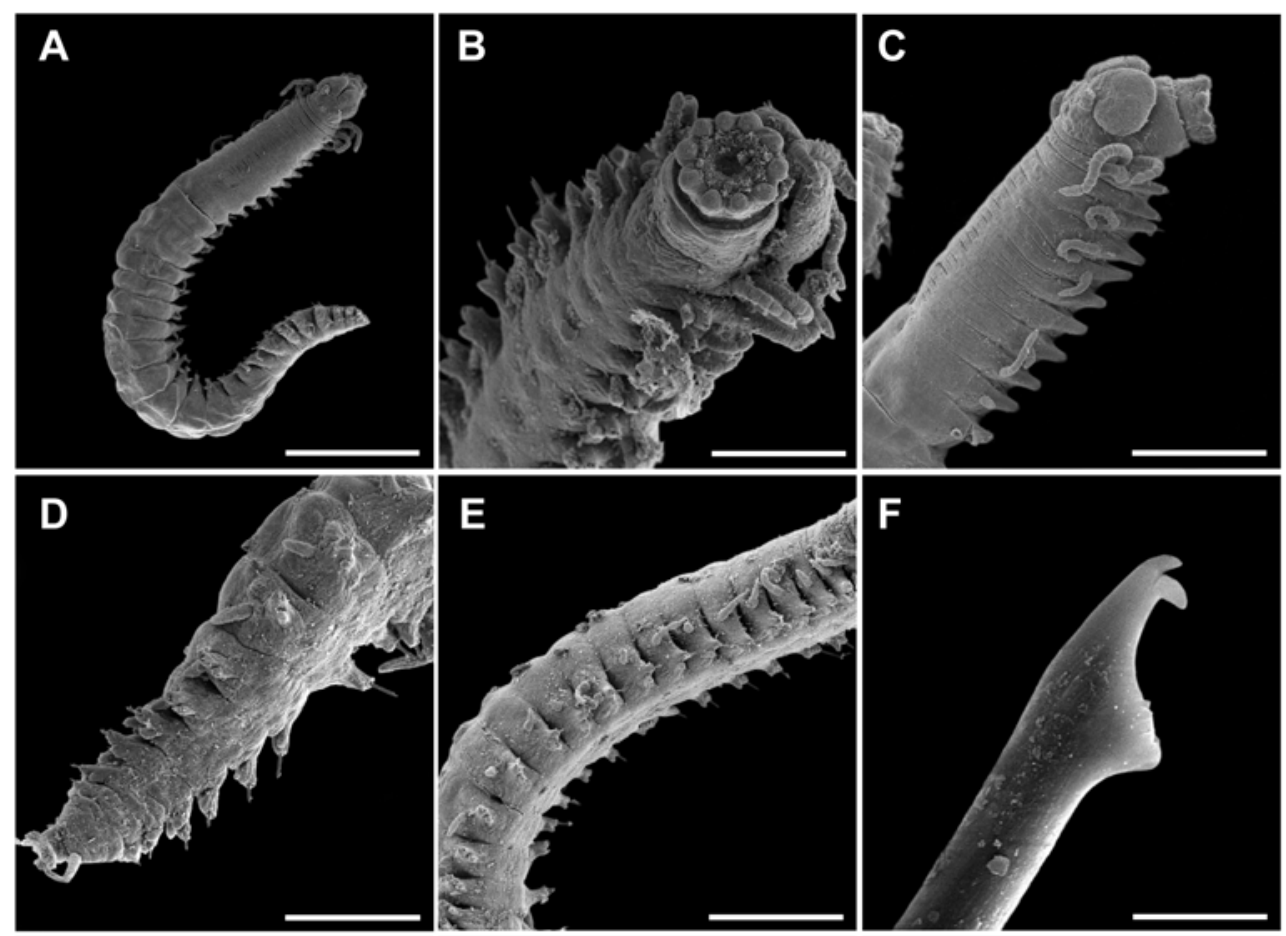

$\mathbf{F}$
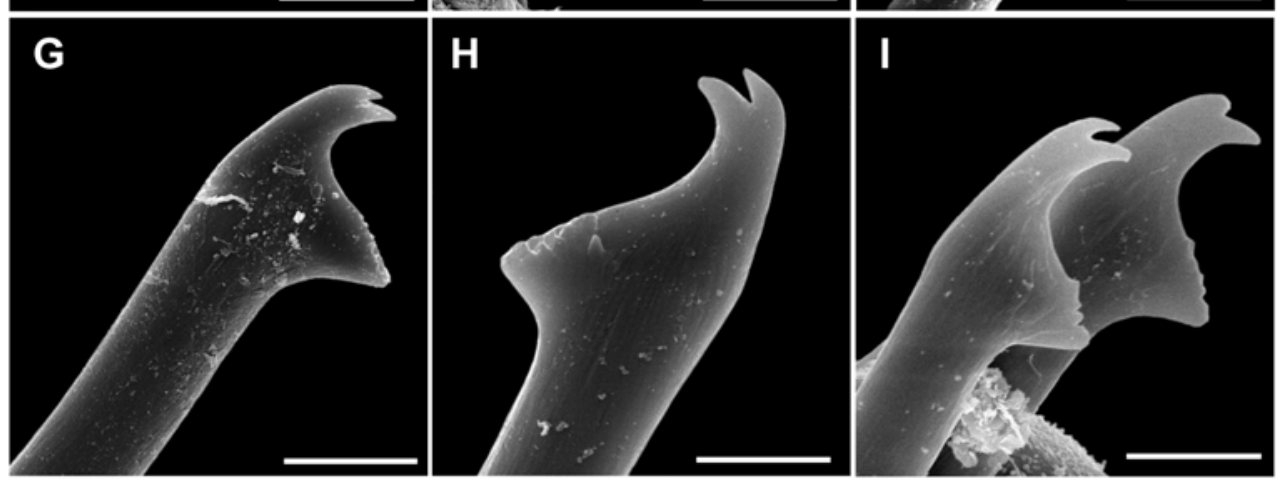

Figure 8. SEM microphotographs of Haplosyllis giuseppemagninoi sp. nov. A) Whole body, ventral view. B) Anterior body, ventral view. C) Anterior body, lateral view. D) Posterior parapodia, ventral view. E) Mid-body parapodia, lateral view. F) Anterior chaeta. G, H) Mid-body chaeta. I) Chaetae from most posterior segments. Scale bars: $\mathrm{A}=600 \mu \mathrm{m} ; \mathrm{B}, \mathrm{D}=176 \mu \mathrm{m} ; \mathrm{C}, \mathrm{E}=300 \mu \mathrm{m} ; \mathrm{F}=4 \mu \mathrm{m} ; \mathrm{G}-\mathrm{H}=3 \mu \mathrm{m} ; \mathrm{I}=$ $5 \mu \mathrm{m}$. Paratypes (MNCN 16.01/13173).
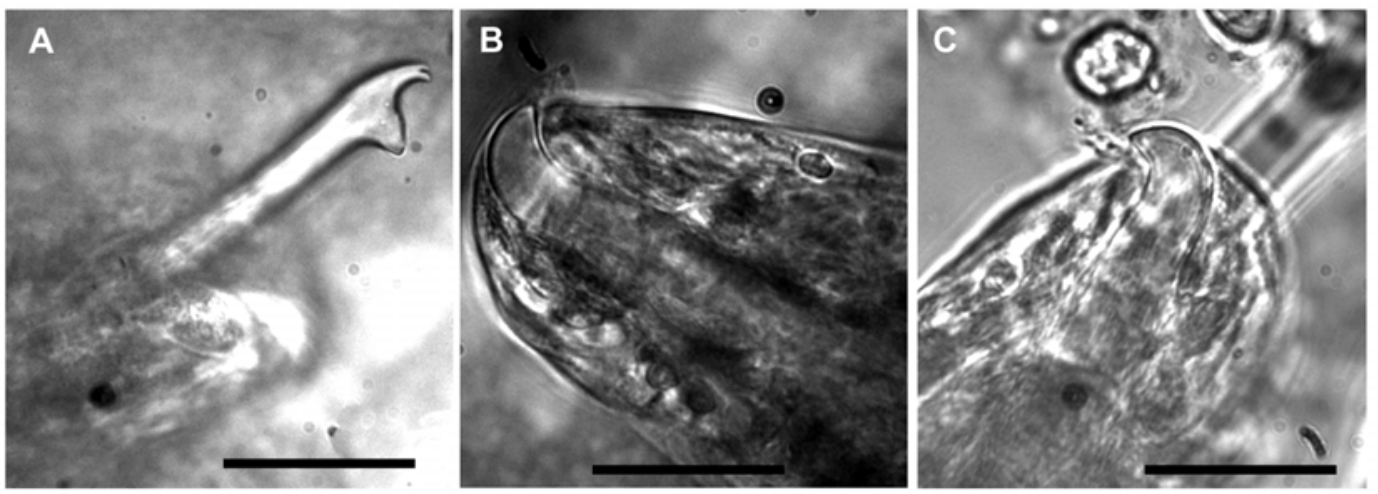

Figure 9. Light microphotographs of Haplosyllis giuseppemagninoi sp. nov. A) Mid-body chaeta. B) Mid-body acicula. C) Acicula from most posterior segments. Scale bars $20 \mu \mathrm{m}$. Paratype (MNCN $16.01 / 13173)$. 